

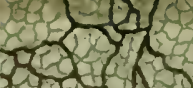





\section{UNIVERSITY OF ILLINOIS}

\section{Agricultural Experiment Station}

BULLETIN NO. 222

FIELD EXPERIMENTS IN SPRAYING APPLE ORCHARDS FOR THE CONTROL OF APPLE BLOTCH

By A. J. GUNDERSON

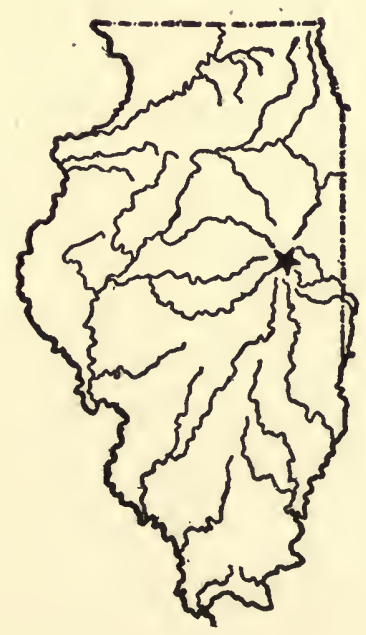

URBANA, ILLINOIS, SEPTEMBER, 1919 


\section{Contents of Bulletin No. 222}

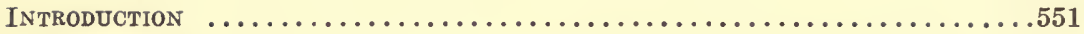

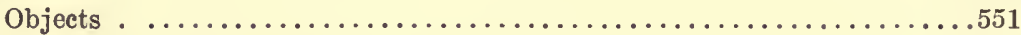

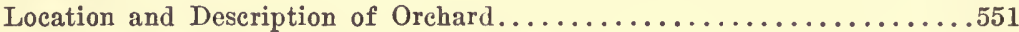

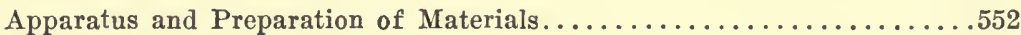

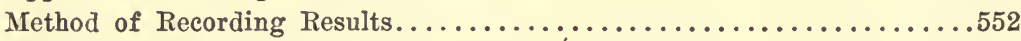

Weather Conditions as Affecting Blotch..................... 553

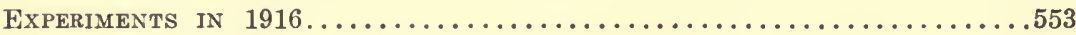

Relative Values of Bordeaux and Lime Sulfur.................553

Value of Different Applications of Bordeaux and Lime Sulfur..........555

Effect of Interchanging Bordeaux and Lime Sulfur................. . . . . . . . .

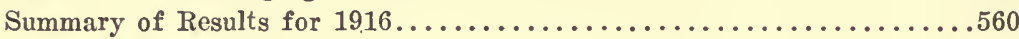

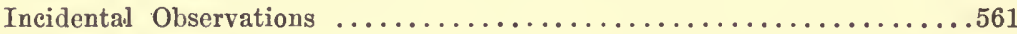

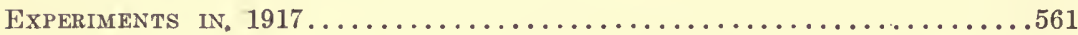

Effect of Dormant Applications of Copper Sulfate, Scalecide, Lime Sul-

fur, and Lime-Sulfur Copper-Sulfate Mixture...............563

Relative Values of Bordeaux and Lime Sulfur.................563

Value of Different Applications of Bordeaux and Lime Sulfur........565

Affect of the Addition of Arsenate of Lead to Lime Sulfur..........568

Relative Merits of Dusting and Liquid Spraying...................568



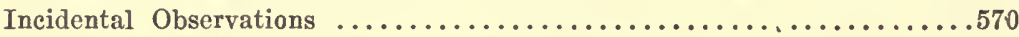

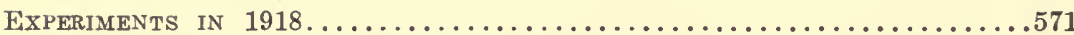

Relative Values of Bordeaux and Lime Sulfur...............571

Value of Different Applications of Bordeaux and Lime Sulfur........573

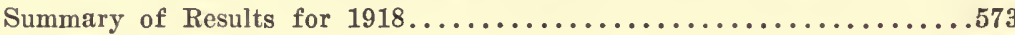

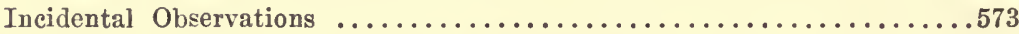

Recommendations for the Control of Apple Blotch............. 575 


\title{
FIELD EXPERIMENTS IN SPRAYING APPLE ORCHARDS FOR THE CONTROL OF APPLE BLOTCH
}

\author{
By A. J. GUNDERSoN, Associate in Pomology
}

\section{INTRODUCTION}

Apple blotch is the most destructive fungous disease of apple orchards in southern Illinois and during the past few seasons observations have disclosed its presence in certain apple orchards of central and western Illinois. There is no question but that blotch is spreading northward but it is doubtful if the orchards of northern Illinois will ever become seriously infected.

Damage caused by apple blotch is two-fold, consisting in injury to the fruit in the form of spotting, which reduces its commercial value, and in canker infection of small limbs, twigs, and fruit spurs, which reduces the productiveness of the trees. Infection of the wood is actually killing hundreds of Duchess apple trees in southern Illinois and in a large measure is responsible for the weakened and unproductive condition of hundreds of Ben Davis and Gano trees in the southern counties of the state.

In view of such conditions it was considered important that methods of spraying for the control of apple blotch be tested.

\section{ОвJестS}

Spraying experiments on the control of apple blotch were carried on during the years 1916, 1917, and 1918 at Flora. The chief objects of these investigations were to study the following points in the control of blotch: (1) the relative values of Bordeaux and lime sulfur; (2) the value of different applications of Bordeaux and lime sulfur; (3) the effect of interchanging Bordeaux and lime sulfur; (4) the cffect of dormant applications of copper sulfate, Scalecide, lime sulfur, and a combination of lime sulfur and copper sulfate; (5) the effect of the addition of arsenate of lead to lime sulfur; and (6) the relative values of dusting and spraying.

\section{LOCATION AND DESCRIPTION OF ORChaRd}

Experiments were conducted in the Suggett orchard, located about one and one-half miles southeast of Flora. The orchard consisted of thirty-eight acres of eighteen-year-old Ben Davis. At the beginning 
of the work in 1916 the trees were in very poor condition, owing to lack of nutrition, diseases, and the fact that no spraying or pruning had been done for years. The result was that every tree in the orchard was seriously infected with apple blotch, cankers appearing on twigs, water sprouts, and fruit spurs. Bitter-rot and black-rot cankers were also present to some extent. The tops of the trees were very dense and contained considerable dead wood.

In laying out the experiments, the orchard was divided into plats containing four trees each, except in the case of the dusted plat, which contained twenty-six trees. A check, or unsprayed, row was left thru the entire length of the orchard.

\section{Apparatus and Preparation of Materials}

Whenever Bordeaux was used in these treatments it was made according to the following formula: 6 pounds of copper sulfate and 8 pounds of lime in 100 gallons of water.

For dormant spraying, copper sulfate was used at the rate of 8 pounds in 100 gallons of water; commercial lime sulfur at the rate of 11 gallons in 100 gallons of water; Scalecide at the rate of 6 gallons in 100 gallons of water; and lime-sulfur and copper-sulfate mixture at the rate of 11 gallons of commercial lime sulfur and 8 pounds of copper sulfate in 100 gallons of water.

For summer spraying commercial sulfur was used at the rate of $21 / 2$ gallons in 100 gallons of water. Powdered arsenate of lead was used at the rate of 2 pounds in 100 gallons of water. The dust mixture used was composed of 85 percent superfine sulfur and 15 percent powdered arsenate of lead.

During 1916 all sprays were applied with a Hardie No. 32 hand outfit, at about 125 pounds pressure. In 1917 and 1918, a triplex Bean sprayer was used with pressure ranging from 175 to 250 pounds. During 1916 and 1917, rods and dise nozzles were used in spraying the trees, while in 1918 spraying was done from the ground with a Bean spray gun, and from the tower with rod and disc nozzles. Severe lime-sulfur injury to foliage due to drenching with the spray gun resulted in discontinuing its use after the first three summer sprays had been applied. The dust was applied by means of a dusting machine of small type driven by a $11 / 2$ horse-power engine.

\section{Method of Recording Results}

Records were kept thruout the season on the appearance of the foliage with regard to fungi, insects, spray injury, and vigor. At harvest time two representative trees from each sprayed plat were picked and all the apples placed on a sorting table and counted. From these, two hundred apples were chosen at random and carefully 
examined. The fruit from three representative unsprayed trees, one at each end and one in the center of the check row, was similarly handled, and the results averaged.

\section{Weather Conditions as Afrecting Blotch}

Weather conditions affect the development of most fungous diseases. Differences of opinion exist, however, as to what conditions are most favorable to blotch development. Scott and Rorer claim that blotch develops in cool or warm weather, but that rains or heavy dews are necessary to the germination of the spores and their spread from cankers to the fruit. Lewis states that blotch develops equally well in either dry or wet weather, but says nothing about the effect of rain upon spore dissemination.

During 1916 and 1918 frequent showers occurred at Flora during the period from four to six weeks after the fall of the bloom. In these years blotch infection on unsprayed trees was 93.24 and 94.0 percent respectively. During the same period in 1917, little rain fell and blotch infection on unsprayed trees was $\mathbf{7 5 . 5}$ percent. Certain commercial orchards in southern Illinois appeared to have less blotch on the fruit in 1917 than in 1916 and 1918. During the period from four to six weeks after the fall of the bloom in 1916, 1917, and 1918, the temperature at Flora averaged between 65 and 70 degrees. The amount and frequency of the rainfall, therefore, appeared to be the factor which caused greater dissemination of spores and offered excellent conditions for their growth.

During the season of 1918 frequent rains prevented a good deal of spraying in commercial orchards in central and southern Illinois, with the result that there was unusual opportunity for blotch infection and the disease actually proved very serious. Then, too, such rains rendered the sprays that were applied less effective.

\section{EXPERIMENTS IN 1916}

Experiments in 1916 were conducted with reference to: (1) the relative values of Bordeaux and lime sulfur as sprays for blotch; (2) the value of different applications of Bordeaux and lime sulfur as sprays for blotch; and (3) the effect on blotch control of interchanging Bordeaux and lime sulfur.

\section{Relative Values of Bordeaux and Lime Sulfur}

Spraying investigations, previously conducted, both in Illinoiş and in other states, had shown Bordeaux to be from slightly to consid- 


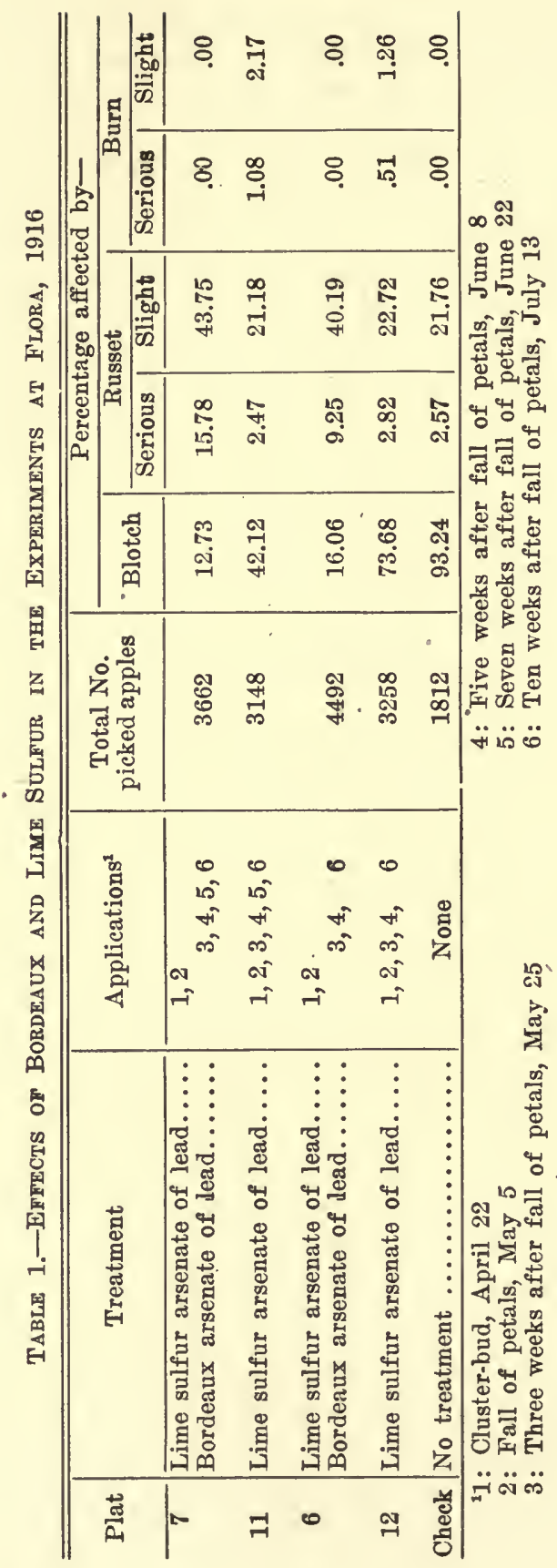


erably more effective than lime sulfur in the control of bloteh. ${ }^{1}$ Such results, however, could not be considered complete. The fact that lime sulfur in some cases had given good results, altho not equal to those from Bordeaux, made further comparative tests of these materials advisable. Then, too, the injurious effect of Bordeaux upon the fruit, following applications against blotch in southern Illinois orchards, emphasized the need of an effective substitute.

As a further test of the relative values of Bordeaux and lime sulfur as sprays for blotch on Ben Davis in southern Illinois, the plats were sprayed with these materials as shown in Table 1.

The data presented show that Bordeaux was decidedly superior to lime sulfur in the control of blotch. In Plat 7, where Bordeaux was applied three, five, seven and ten weeks after the fall of the petals, there was 12.73 percent blotch, as compared with 42.12 percent blotch on Plat 11, which was sprayed with lime sulfur at the same periods. A similar comparison is presented between Plat 6, which was sprayed with Bordeaux three, five, and ten weeks after the fall of the petals, resulting in 16.06 percent blotch, and Plat 12, which was sprayed with lime sulfur at these three periods, and showed 73.68 percent blotch. The unsprayed row showed 93.24 percent blotch.

Very usual differences between the effect of the two sprays upon the fruit is shown in the russet column. Plats 11 and 12, which were sprayed with lime sulfur, alone, show about the same percentage of russet as the unsprayed row. It may be concluded, therefore, that something other than the spray russetted the fruit. As regards Plats 6 and 7, which were sprayed with Bordeaux three and four times, respectively, it will be noted, after subtracting the amount of russet on the unsprayed row, that the Bordeaux caused a good deal of russet.

Plats 11 and 12 show a small percentage of lime-sulfur burn. This developed a few days following the application of lime sulfur arsenate of lead made in mid-July, when the temperature was extremely high. It occurred on the fruit which had received too much spray and was therefore confined to scattered areas of the trees.

\section{Value of Different Applications of Bordeaux and Lime Sulfur}

Scott and Rorer found, from investigations carried on in Arkansas during 1907, that the principal blotch infection on apples occurred from four to six weeks after the fall of the petals, and that scattering infections continued to take place thruout the season. ${ }^{2}$ They recom-

\footnotetext{
${ }^{1}$ U. S. Dept. Agr. Bur. Plant Indus. Circ. 54, p. 13. 1910. Kans. Agr. Exp. Sta. Bul. 196. 1913. Ill. Agr. Exp. Sta. Bul. 185, p. 111.1916.

${ }^{2}$ U. S. Dept. Agr. Bur. Plant Indus. Bul, 144, p. 21. 1909.
} 


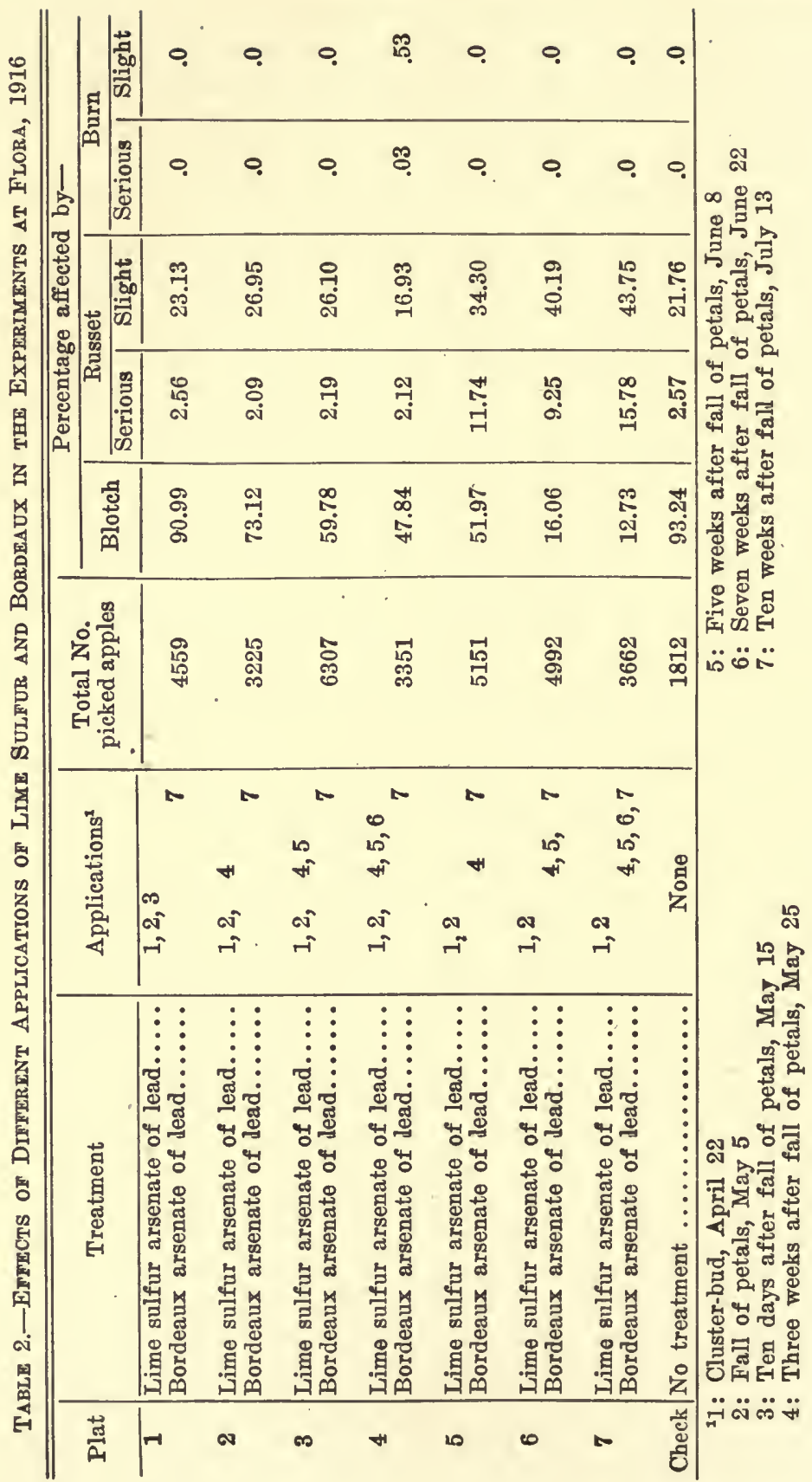


mended applying four sprays of Bordeaux: the first, three to four weeks after the fall of the petals; a second about four weeks later; and a third and fourth at three-week intervals thereafter. The purpose of these applications was to keep the fruit well coated with spray until picking time. The number of applications, however, would depend upon the season, a wet one requiring more sprays than a dry one. Lewis has reported that in Kansas the greatest blotch infection occurs from four to six weeks after the fall of the petals, and continues during the remainder of the growing season, or at least until the last of August. ${ }^{1} \mathrm{He}$ recommended the use of Bordeaux during dry weather and lime sulfur in a wet season, to be applied three, five to seven, and ten weeks after the fall of the petals.

For the purpose of gaining information on the value of different applications of Bordeaux and lime sulfur as sprays for blotch under conditions in southern Illinois, plats were sprayed with these materials as shown in Table 2. It will be noted that sprays applied at the cluster-bud stage, at the fall of the petals, and ten weeks thereafter were the same for all plats, as it was the purpose to compare the values of only the other applications.

The data presented for Plat 1 show that where lime sulfur was applied ten days after the fall of the petals, 90.99 percent blotch developed on the fruit. When comparison of this figure is made with the percentage of blotch present on the unsprayed row, 93.24 percent, it will be seen that lime sulfur applied ten days after the fall of the petals was practically of no value in controlling blotch. Plat 2, sprayed with lime sulfur three weeks after the fall of the petals, shows 73.12 percent blotch, which in comparison with the amount on the unsprayed row represents a control of 20.12 percent. Plat 3, sprayed with lime sulfur three and five weeks after the fall of the petals, shows 59.78 percent blotch, or 33.46 percent control, of which 20.12 percent may be attributed to the spray three weeks after the fall of the petals, leaving 13.34 percent control due directly to the five-weeks spray. Plat 4, which received lime sulfur three, five, and scven weeks after the fall of the petals, shows 47.84 percent blotch, or 45.40 percent control. Since 33.46 percent control was exerted by the three and five weeks sprays of lime sulfur, it may be concluded that lime sulfur applied seven weeks after the fall of the petals controls bloteh to the extent of 11.94 percent.

Plat 5, sprayed with Bordeaux three weeks after the fall of the petals, shows 51.97 percent bloteh, or 41.27 percent control. Plat 6, where Bordeaux was applied three and five weeks after the fall of the petals, shows 16:06 percent bloteh, or 77.18 percent control.' Since

${ }^{1}$ Kans. Agr. Exp. Sta. Bul. 196. 1913. 


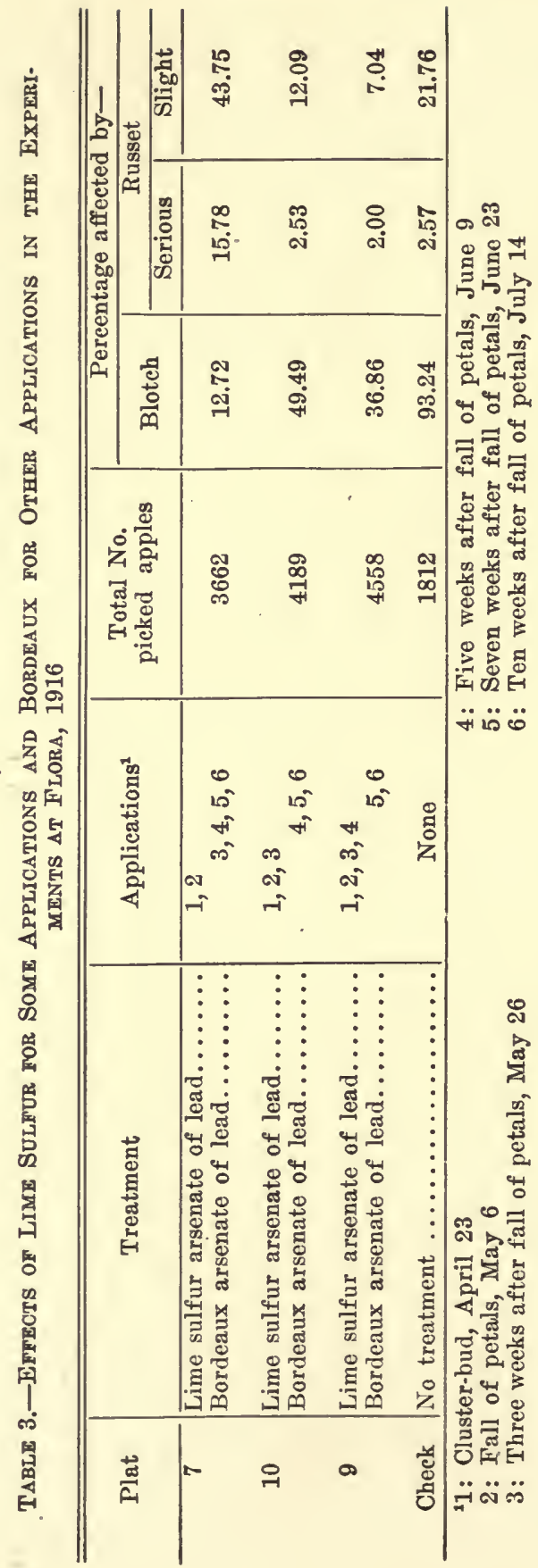


41.27 percent control was excrted by the three weeks spray, Bordeaux applied five weeks after the fall of the petals actually gave 35.91 percent control. On Plat 7, where Bordeaux was applied three, five, and seven weeks after the fall of the petals, there was 12.73 percent blotch, or 80.51 percent control. Since the three- and five-weeks sprays of Bordeaux gave a combined control of 77.18 percent, the actual blotch control exerted by the seven weeks spray was 3.33 percent.

In percentages of russet present important differences appear between the effects of lime sulfur and of Bordeaux. It will be noted that the percentages present in Plats 1, 2, 3, and 4, sprayed with lime sulfur, were very nearly the same as the percentage present on the unsprayed row; hence the conclusion is that something other than the sprays caused this injury. Reference to Plats 5,6 , and 7 will show that considerable russet appeared on the fruit. Since it was observed in the orchard that russeting of the fruit occurred prior to July 1, and since Plat 5, sprayed with Bordeaux three weeks after the fall of the petals, showed more russet than was present on Plat 6 and almost as much as was present on Plat 7, it may be concluded that the application of Bordeaux three weeks after the fall of the petals caused the russet on all of the plats minus the percentage which appeared on the unsprayed row.

It will be noted that no burn appeared on Plats 1,2 , or 3 , but that a small amount appeared on Plat 4, due to lime sulfur arsenate of lead applied seven weeks after the fall of the petals during very hot, dry weather.

\section{Effect of Interchanging Bordeaux and Lime Sulfur}

During the wet season of 1915 certain growers in southern Illinois reported serious russeting of fruit even tho Bordeaux had been used three weeks after the fall of the petals, and even later. Such an occurrence is rare, altho experiments conducted by this station in 1912 showed that Bordeaux applied three weeks after the fall of the petals caused 33.1 percent slight russet. ${ }^{1}$ Investigations on the control of blotch have shown that the first and most important spray is the one applied three or four weeks after the fall of petals. ${ }^{2}$ Since russetting of the fruit may follow such an application and applications made still later, it was thought that lime sulfur, which usually does not cause russet, might be substituted for Bordeaux at these times. Accordingly sprays were applied as shown in Table 3. The first, second, and sixth applications wcre the same in all plats.

${ }^{1}$ Ill. Agr. Exp. Sta. Bul. 185, p. 179. 1916.

${ }^{2}$ U. S. Dept. Agr. Bur. Plant. Bul. 144, p. 22. 1909. Kans. Agr. Exp. Sta. Bul. 196 , p. 572 . 1913. 
The results show that in Plat 7 , where Bordeaux was applied three, five, and seven weeks after the fall of the petals, there was 12.73 percent blotch. In Plat 10, where lime sulfur was substituted for Bordeaux in the spray three weeks after the fall of the petals, there was 49.49 percent blotch. In Plat 9, where lime sulfur was substituted for Bordeaux in the sprays three and five weeks after the fall of the petals, there was 36.86 percent blotch. These results show that lime sulfur did not control blotch as well as Bordeaux when substituted for the latter spray either three or five weeks after the fall of the petals.

It will be noted that in Plat 10 the substitution of lime sulfur for Bordeaux in the spray three weeks after the fall of the petals eliminated the russet factor but did not satisfactorily control blotch. The same is true for Plat 9, where lime sulfur was substituted-for Bordeaux in the sprays applied three and five weeks after the fall of the petals. The russet present on the fruit of Plats 9 and 10 was caused by something other than the sprays, since the unsprayed row shows 2.57 percent serious and 21.76 slight russet. By subtracting these amounts from the percent of russet for Plat 7 , it will be found that Bordeaux applied three weeks after the fall of the petals actually caused 13.21 percent serious and 21.99 percent slight russet.

\section{SUMmary of RESULtS FOR 1916}

1. Bordeaux proved superior to lime sulfur as a spray for blotch.

2. The most important sprays in the control of blotch were those applied three and five weeks after the fall of the petals; when applied seven weeks after the fall of the petals these sprays were of less value. Lime sulfur applied ten days after the fall of the petals failed to exert any control over blotch.

3. Individual sprays of Bordeaux applied three, five, or seven weeks after the fall of the petals proved superior to similar individual applications of lime sulfur. This superiority may have been due to the greater adhesiveness of Bordeaux.

4. Bordeaux applied three weeks after the fall of the petals russetted the fruit.

5. The substitution of lime sulfur for Bordeaux three or five weeks after the fall of the petals eliminated russet but failed to control blotch. The russet caused by Bordeaux applied three weeks after the fall of the petals was less injurious to the quality and the appearance of the fruit than was the increase in amount of blotch caused by substituting lime sulfur for Bordeaux at this application. 


\section{INCIDENTAL OBSERVATIONS}

1. Blotch appeared on the fruit of the unsprayed row about June 15, six weeks after the fall of the petals. Later in the season it was detected on the foliage both of unsprayed and of sprayed trees, particularly in the interiors of the trees.

2. At picking time it was seen that the greatest blotch infection on the sprayed trees appeared on the fruit located on the interior parts of the trees, where the foliage was very dense. The sprays would doubtless have been more effective if the trees had been thoroly pruned. On blotch-infected trees water sprouts are usually more seriously effected by the disease because the fungus seems to thrive better on such new, tender wood. Thoroness of application to the interior of the tree is therefore essential; the spray should cover not only the fruit and foliage but also the new growth in order to prevent the formation of cankers thereon. When spraying trees for blotch, pressures of 200 to 225 pounds should be used and the man on the ground should direct the spray to the interior parts of the trees and to the undersides of fruit and branches.

3. Some spray injury to foliage resulted from the use of both Bordeaux and lime sulfur.

4. Lime sulfur arsenate of lead applied during the hot weather of mid-July caused a negligible amount of burn on the fruit; that the injury was not greater was probably due to the fact that the trees were not drenched.

\section{EXPERIMENTS IN 1917}

The results obtained at Flora in 1916 had thoroly demonstrated that before the most thoro and effective spraying can be done against blotch, the trees must be pruned so as to open up the tops. The results had also demonstrated that cankered water sprouts, which are usually a serious source of infection, should be removed. Accordingly this work was thoroly done during the winter of 1916-17 preparatory to the experiments of 1917.

The experiments of 1916 had also shown that 125 pounds pressure is insufficient if a fine penetrating spray is desired, and in order to obtain high pressures, a power sprayer was secured for the season of 1917.

Spraying investigations at Flora during 1917 were conducted to determine the following points in the control of blotch: (1) the effect of dormant applications of copper sulfate, Scalecide, lime sulfur, and lime-sulfur copper-sulfate mixture; (2) the relative value of Bordeaux and lime sulfur; (3) the value of different applications of Bordeaux and lime sulfur; (4) the effect of the addition of arsenate of lead to lime sulfur; and (5) the relative merits of dusting and liquid spraying. 
Table 4.-Effects of Dormant Applications of Copper Sulfate, Scalecide, Lime Sulfur, and Lime Sulfur Copper Sulfate in the EXPERMENTS AT FLORA, 1917

\begin{tabular}{|c|c|c|c|c|}
\hline Plat & Treatment & Applications ${ }^{1}$ & $\begin{array}{l}\text { Total No. } \\
\text { picked apples }\end{array}$ & $\begin{array}{l}\text { Percentage } \\
\text { affected } \\
\text { by blotch }\end{array}$ \\
\hline 1 & $\begin{array}{l}\text { Copper sulfate } \ldots \ldots \ldots \ldots \ldots \\
\text { Lime sulfur arsenate of lead. }\end{array}$ & $1_{2,3,4,5,6,7}$ & 1580 & 7.0 \\
\hline 2 & $\begin{array}{l}\text { Scalecide } \ldots . . . . . . . . . . . . \\
\text { Lime sulfur arsenate of lead }\end{array}$ & ${ }^{1} 2,3,4,5,6,7$ & 2010 & 14.0 \\
\hline 3 & $\begin{array}{l}\text { Lime sulfur. ................ } \\
\text { Lime sulfur arsenate of lead }\end{array}$ & ${ }^{1} 2,3,4,5,6,7$ & 1468 & 10.0 \\
\hline 4 & $\begin{array}{l}\text { Lime sulfur copper sulfate.. } \\
\text { Lime sulfur arsenate of lead }\end{array}$ & ${ }^{1} 2,3,4,5,6,7$ & 2500 & 16.0 \\
\hline 5 & Lime sulfur arsenate of lead. & $2,3,4,5,6,7$ & 2471 & 6.5 \\
\hline 6 & $\begin{array}{l}\text { Copper sulfate ........... } \\
\text { Lime sulfur arsenate of lead } \\
\text { Bordeaux arsenate of lead... }\end{array}$ & $\begin{array}{lll}1 & & \\
& 2,3 & \\
& & 4,5,6,7\end{array}$ & 1891 & 9.0 \\
\hline 7 & $\begin{array}{l}\text { Scalecide } \ldots . . . . . . . . . . . \\
\text { Lime sulfur arsenate of lead } \\
\text { Bordeaux arsenate of lead... }\end{array}$ & $\begin{array}{lll}1 & & \\
& 2,3 & \\
& & 4,5,6,7\end{array}$ & 2960 & 11.5 \\
\hline 8 & $\begin{array}{l}\text { Lime sulfur................ } \\
\text { Lime sulfur arsenate of lead } \\
\text { Bordeaux arsenate of lead... }\end{array}$ & 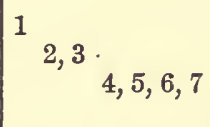 & 1986 & 9.5 \\
\hline 9 & $\begin{array}{l}\text { Lime sulfur copper sulfate.. } \\
\text { Lime sulfur arsenate of lead } \\
\text { Bordeaux arsenate of lead... }\end{array}$ & 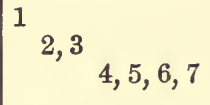 & 1504 & 13.0 \\
\hline 10 & $\begin{array}{l}\text { Lime sulfur arsenate of lead } \\
\text { Bordeaux arsenate of lead... }\end{array}$ & ${ }^{2,3} 4,5,6,7$ & 1897 & 8.5 \\
\hline Check & No treatment ............. & None & 1101 & 75.5 \\
\hline
\end{tabular}

1: Dormant, March 31

2: Cluster-bud, April 20

3: Fall of petals, May 7
4: Three weeks after fall of petals, May 28 5: Five weeks after fall of petals, June 12 6: Seven weeks after fall of petals, June 26 7: Ten weeks after fall of petals, July 17 
Effect of Dormant Applications of Copper Sulfate, Scalecide, Lime Sulfur, and Lime-Sulfur Copper-Sulfate Mrxture

Certain apple growers in this state had expressed the belief that a dormant application of lime-sulfur or copper-sulfate solution will reduce blotch infection, presumably by destroying the cankers. No experimental evidence, however, was available on this point. In 1907 this station reported on tests involving the spraying of bitter-rot cankers with copper-sulfate solution both in the laboratory and in the field. The results of such experiments demonstrated that bitterrot cankers could not be destroyed by an external application of copper sulfate. ${ }^{1}$ It was thought, however, that since the mycelium of blotch fungus works just beneath the bark or the epidermis, a dormant spray of certain soluble materials might penetrate the diseased tissues and destroy the mycelium.

In conjunction with the plat tests, the results of which are presented in Table 4, ten one-year-old blotch cankers on water sprouts were sprayed with copper sulfate, Scalecide, lime sulfur, and limesulfur copper-sulfate mixture. The sprays were applied on March 30 by means of an atomizer. Ten cankers were left unsprayed to be used as checks.

The data presented show that a dormant application of copper sulfate, Scalecide, lime sulfur, or lime-sulfur copper-sulfate mixture had no effect on the blotch. Plats 1, 2, 3, and 4, which received dormant applications of the various sprays followed by summer sprays of lime sulfur arsenate of lead showed more blotch than Plat 5, which received no dormant spray, but the same summer applications. A similar difference will be noted between Plats $6,7,8$, and 9 , which received dormant applications of the various spray materials followed by summer sprays of lime sulfur arsenate of lead and Bordeaux arsenate of lead, and Plat 10 , which received no dormant spray but the same summer applications.

The check plat showed 75.5 percent blotch.

These results were further substantiated by the data secured from the blotch cankers on water sprouts sprayed with an atomizer. Examination of these cankers early in September showed that in no case had the sprays checked the growth of the cankers. The cankers had continued their growth and had formed new pycnidia, or sporebearing cases, and altho no examinations were made for spores, it is reasonable to conclude that these were produced.

\section{Reuative Values of Bordeaux and Lime Sulfur}

In the experiments at Flora in 1916 Bordeaux had proved superior to lime sulfur in the control of blotch. However, as the orchard had not been pruned in many years, it had been impossible to make

${ }^{1}$ IIl. Agr. Exp. Sta. Buls. 117 and 118. 1907. 


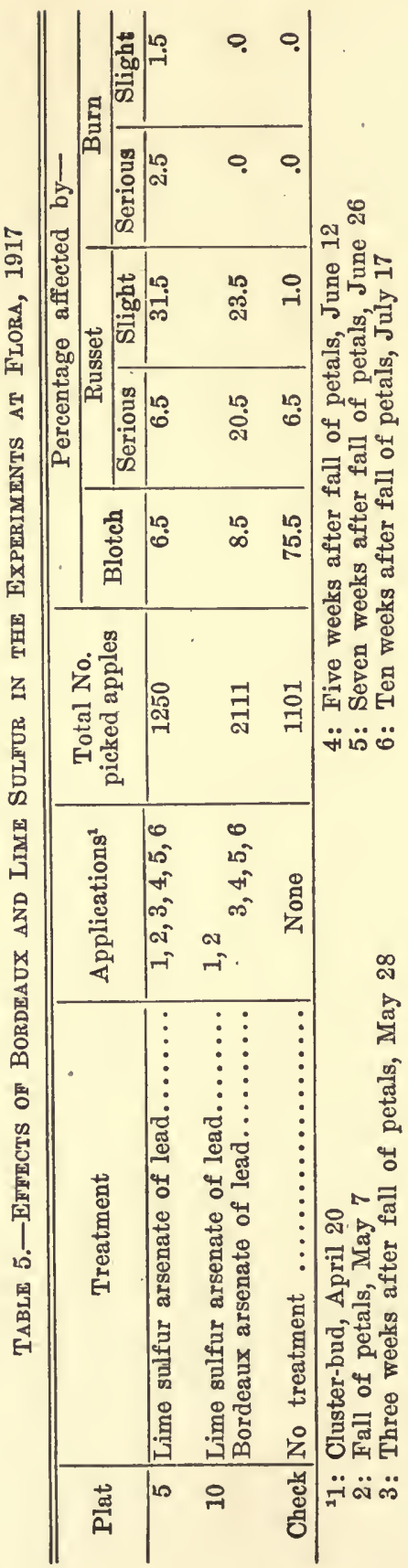


thoro applications and it was thought that with good pruning the results might be different. As previously stated, the trees were well pruned during the winter of 1916-17 and in 1917 tests were again made with Bordeaux and lime sulfur. Sprays were applied at 225 pounds pressure.

The results in Table 5 show that lime sulfur was slightly superior to Bordeaux in the control of blotch, but the difference is so slight that both sprays may be considered equally effective.

The presence of russet on the fruit of both Plat 5 and Plat 10 is a rather interesting point. Bordeaux russet is a common form of fruit injury; lime-sulfur russet, however, is unusual. It will be seen by deducting the percentages of russet present on the unsprayed row from those on the sprayed plats that lime sulfur caused 30.5 percent slight russet and Bordeaux 14 percent serious and 22.5 percent of slight russet.

Lime sulfur caused 2.5 percent serious and 1.5 percent slight burn. This injury followed the application made ten weeks after the fall of the petals, during very warm, dry weather.

\section{Value of Different Applications of Bordeaux and Lime Sulfur}

Experiments conducted at Flora in 1916 had shown that the most important Bordeaux and lime-sulfur sprays for blotch were those applied three and five weeks after the fall of the petals; that when applied seven weeks after the fall of the petals, these sprays were of less value. It had also been found that lime sulfur applied ten days after the fall of the petals exerted no control over blotch. As a further test of the value of different applications of lime sulfur and Bordeaux as sprays for blotch, plats were sprayed in 1917 as shown in Table 6.

The results presented for Plats 11 and 12 and Plats 16 and 17 show that the most important lime-sulfur and Bordeaux sprays against blotch were those applied three and five weeks after the fall of the petals. Such information confirms results obtained at Flora in 1916. These facts emphasize the importance of timeliness of application. It will be noted further that lime sulfur applied seven, ten, and twelve weeks after the fall of the petals caused some reduction in the amount of bloteh. It is to be remembered that the greatest blotch infection occurs from four to six weeks after the fall of the petals, but that scattering infections may take place thruout the rest of the season, or young apples infected early may become a source of later infection to fruit and wood. Such conditions may explain the control exerted by spray applied seven, ten, and twelve weeks after the fall of the petals. Similar results were obtained from Bordeaux applied seven and ten weeks after the fall of the petals. 


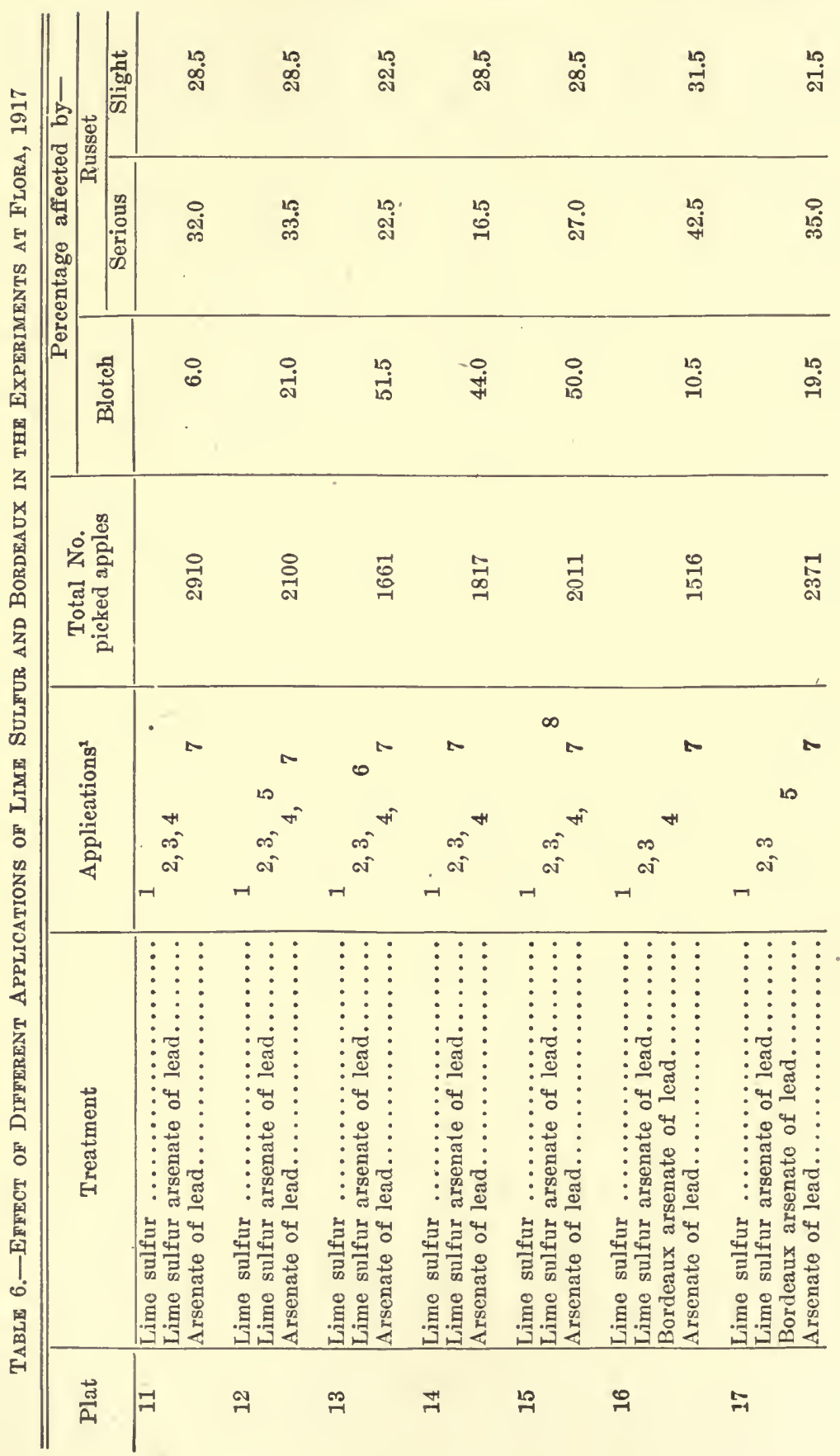




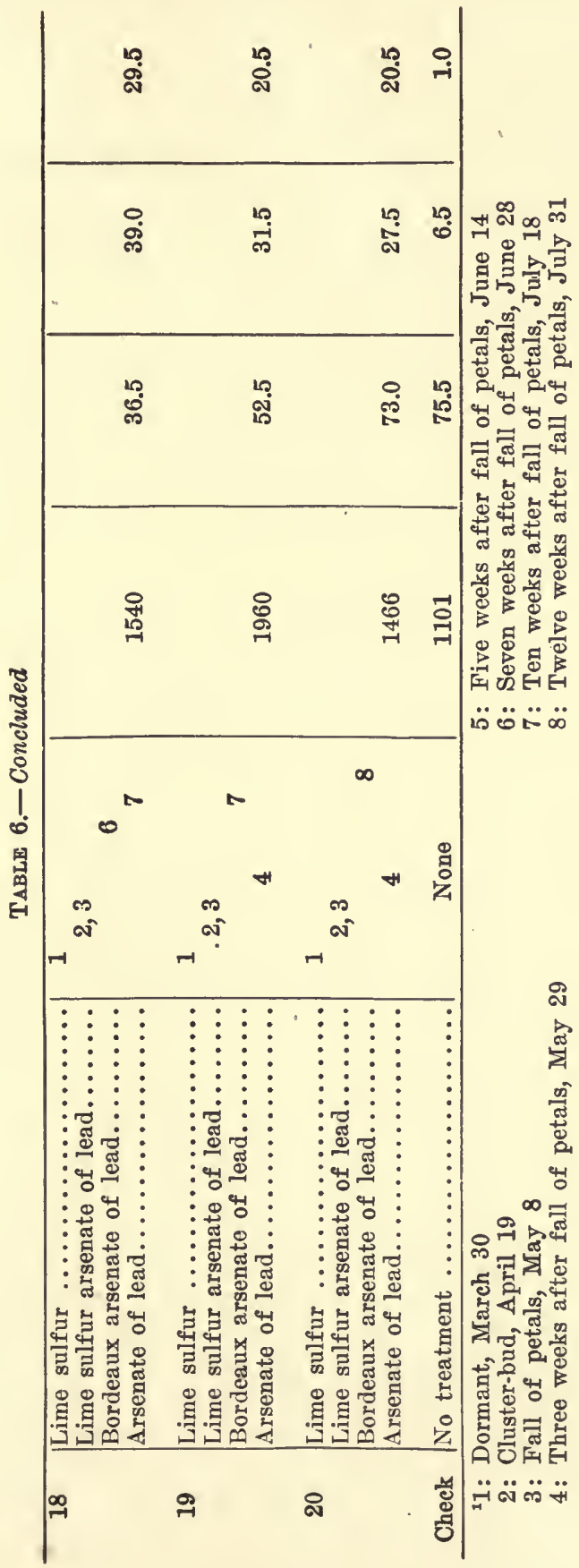


It will be noted that Bordeaux applied twelve weeks after the fall of the petals was of practically no value in controlling blotch.

By deducting the amount of russet on the unsprayed row from that present on the sprayed plats, the true amount of russet caused by the sprays may be found. It is difficult to say definitely which application of lime sulfur caused the russet on Plats 11, 12, 13, 14, and 15, altho it is probable that it was caused by the application made at the fall of the petals, since all the lime-sulfur plats have practically the same amounts of russet.

Plat 16, sprayed with Bordeaux at the fall of the petals, showed considerable russet. This, no doubt, was caused partly by lime sulfur applied at the fall of the petals and partly by Bordeaux applied three weeks later. The russet on Plats 17, 18, 19, and 20 was probably due to lime sulfur applied at the fall of the petals and not to later Bordeaux sprays.

\section{Effect of the Addition of Arsenate of Lead to Lime Sulfur}

In experiments conducted by the writer in 1912, it had been found that the addition of arsenate of lead to lime sulfur slightly increased its value as a spray for scab. ${ }^{1}$ It has been somewhat of a question whether such an addition would increase the value of lime sulfur as a spray for blotch. To determine this point three plats were treated as shown in Table 7. The first three applications, made for the control of scale and scab, were the same on all plats.

The results presented show that Plat 21, which was sprayed threc, five, seven, and ten weeks after the fall of petals with arsenate of lead alone, had 56 percent blotch; Plat 22, sprayed at these times with lime sulfur alone, 17 percent blotch; and Plat 23, sprayed at the same times with lime sulfur arsenate of lead, 19 percent blotch. That arsenate of lead alone had some value as a spray for blotch is seen when reference is made to the percentage of blotch on the unsprayed row, but its addition to lime sulfur can hardly be said to increase the value of that spray in the control of blotch.

\section{Relative Merits of. Dusting and Liquid Spraying}

In order to gain definite information with regard to the comparative values of dusting and liquid spraying in the control of blotch, plats were treated as shown in Table 8.

The results presented show that dusting with a mixture of finely ground sulfur and powdered arsenate of lead failed to exert any control over bloteh, while sprays of lime sulfur arsenate of lead reduced the infection from 75.5 percent on the unsprayed row to 10 percent.

${ }^{1}$ Ill. Agr. Exp. Sta. Bul. 185, p. 185. 
Table 7.-EFrects of the Adpition ol Arsenate of Lead to Lime Sulfur as a SPRAy for Blotch in the Experiments at Flora, 1917

\begin{tabular}{|c|c|c|c|c|}
\hline Plat & Treatment & Applications ${ }^{1}$ & $\begin{array}{l}\text { Total No. } \\
\text { picked apples }\end{array}$ & $\begin{array}{l}\text { Percentage } \\
\text { affected } \\
\text { by blotch }\end{array}$ \\
\hline 21 & $\begin{array}{l}\operatorname{Lim} \theta \text { sulfur } \ldots \ldots \ldots \ldots \ldots \ldots \\
\text { Lime sulfur arsenate of lead.. } \\
\text { Arsenate of lead............ }\end{array}$ & $\begin{array}{lll}1 & & \\
& 2,3 & \\
& & 4,5,6,7 \\
& & \end{array}$ & 970 & 56.0 \\
\hline 22 & 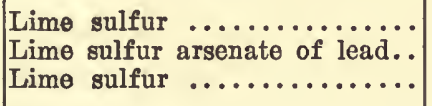 & $\begin{array}{lll}1 & & \\
& 2,3 & \\
& & 4,5,6,7\end{array}$ & 1250 & 17.0 \\
\hline 23 & $\begin{array}{l}\operatorname{Lim} \text { sulfur } \ldots \ldots \ldots \ldots \ldots \ldots \ldots \\
\operatorname{Lim} \theta \text { sulfur arsenate of lead.. }\end{array}$ & ${ }^{1} 2,3,4,5,6,7$ & 972 & 19.0 \\
\hline Check & No treatment ... & None & 1101 & 75.5 \\
\hline
\end{tabular}

1: Dormant, March 30

2: Cluster-bud, April 21

3: Fall of petals, May 8

4: Three weeks after fall of petals, May 25

5: Five weeks after fall of petals, June 13

6: Seven weeks after fall of petals, Juno 27

7: Ten weeks after fall of petals, July 18

Table 8.-EFrects of Dusting aNd Li quid Spraying in the Experiments at FLORA, 1917

\begin{tabular}{|c|c|c|c|c|}
\hline Flat & Treatment & Applications ${ }^{2}$ & $\begin{array}{c}\text { Total No. } \\
\text { picked apples }\end{array}$ & $\begin{array}{l}\text { Percentage } \\
\text { affected } \\
\text { by blotch }\end{array}$ \\
\hline $\mathbf{A}$ & $\begin{array}{l}\text { Lime sulfur } \ldots \ldots \ldots \ldots \ldots \ldots . . . . . . \\
\text { Sulfur-arsenate of lead dust } \\
\quad(85-15) \ldots \ldots \ldots \ldots \ldots \ldots\end{array}$ & $2,3,4,5,6,7$ & 1417 & 83.5 \\
\hline 3 & $\begin{array}{l}\text { Lime sulfur } \ldots . . . \ldots \ldots \ldots . . . \\
\text { Lime sulfur arsenate of lead.. }\end{array}$ & $2,3,4,5,6,7$ & 1586 . & 10.0 \\
\hline Check & No treatment .... & None & 1101 & 75.5 \\
\hline
\end{tabular}

11: Dormant, March 29

2: Cluster-bud, April 19

3: Fall of petals, May 9

4: Three weeks after fall of petals, May 28

5: Five weeks after fall of petals, June 15

6: Seven weeks after fall of petals, June 28

7: Ten weeks after fall of petals, July 17 


\section{SUMmary of RESULTS For 1917}

1. Dormant applications of copper sulfate, Scalecide, lime sulfur, and lime-sulfur copper-sulfate mixture were valueless in checking blotch. Blotch cankers on water sprouts continued to grow and form pycnidia after being sprayed with these materials.

2. Lime sulfur and Bordeaux were practically equally effective in their control of blotch.

3. Both lime sulfur and Bordeaux russetted the fruit, the former in the application made at the fall of the petals and three weeks later, and the latter in the spray applied three weeks after the fall of the petals.

4. Applications of lime sulfur and Bordeaux made three and five weeks after the fall of the petals were the most important sprays in the control of blotch. Lime sulfur exerted the greater degree of control. Applications of these materials made seven, ten, and twelve weeks after the fall of the petals were of decidedly less value in controlling blotch.

5. Arsenate of lead alone possessed some value as a spray for blotch, but the addition of this material to lime sulfur did not increase the value of that spray in the control of blotch.

6. Dusting with a mixture of 85 pounds of finely ground sulfur and 15 pounds, of powdered arsenate of lead was valueless in controlling blotch, while liquid lime sulfur arsenate of lead gave good results.

\section{InCIDENTAL OBSERVATIONS}

1. The experimental work at Flora in 1917 again emphasized the importance of pruning trees infected with blotch. Pruning out dead wood, crossing branches, and water sprouts facilitated spraying. Blotch cankers develop more readily on water sprouts, thus increasing the danger of infection on fruit and new growth. They should therefore be removed.

2. Timeliness of application is the first essential in controlling blotch. Thoroness is the next important item and this ean be attained only by means of high pressures, 200 to 225 pounds, using dises with small openings that will produce a fine mist. Trees should be sprayed in the interior and underneath as well as from the outer sides.

3. Apple blotch was first observed on the unsprayed fruit on June 12, five weeks after the fall of the petals.

4. Blotch must be controlled by the sprays three and five weeks after the fall of the petals, for it cannot satisfactorily be controlled by sprays applied later in the season. 
5. Both Bordeaux and lime sulfur caused some foliage injury. Injury from Bordeaux appeared as brown spots and later as tip and edge burn. Vigorous trees suffered less spray injury to the foliage than weak trees.

6. Dusting trees was not as efficient as liquid spraying in the control of blotch and was much more expensive.

7. The Friend spray gun was found to be wasteful as it gave a much coarser spray than the ordinary dise nozzles.

\section{EXPERIMENTS IN 1918}

The season of 1918 at Flora proved very discouraging not only to experimental workers but to commercial growers as well. The blooming period of Ben Davis extended over a period of ten days in the Suggett orchard, during which time the weather was cool and very wet. A light set of apples resulted in all but a few rows on the west side of the orchard. Following such unfavorable conditions for pollination came the ten-weeks drouth of June, July, and August, which materially reduced the size of the apples.

It was possible to obtain records only on the plats which were concerned with: (1) the relative values of Bordeaux and lime sulfur as sprays for bloteh; and (2) the value of different applications of Bordeaux and lime sulfur as sprays for blotch.

\section{Relative Values of Bordeaux and Lime Sulfur}

Results of experiments in 1917 had shown that Bordeaux and lime sulfur were equally effective in the control of blotch. Further comparison of these two sprays was made in 1918 with the results presented in Table 9.

These data show that Bordeaux and lime sulfur were practically equal in the control of blotch. It will be noted that Plat 1 shows 5 percent more blotch than Plat 2, which difference may have been due to the omission of the spray seven weeks after the fall of the petals.

Results for Plats 3 and 4 show practically an equal amount of blotch. It is very probable that the Bordeaux applied to Plat 4 seven weeks after the fall of the petals was unnecessary, owing perhaps to the adhesiveness of the spray applied five weeks after the fall of the petals. Blotch was greatly reduced on all the sprayed plats, since 94 percent infection appeared on the unsprayed row.

Reference to the russet column will show that both lime sulfur and Bordeaux caused some russet, but more serious russeting occurred on the plats sprayed with Bordeaux than on those sprayed with lime sulfur. 


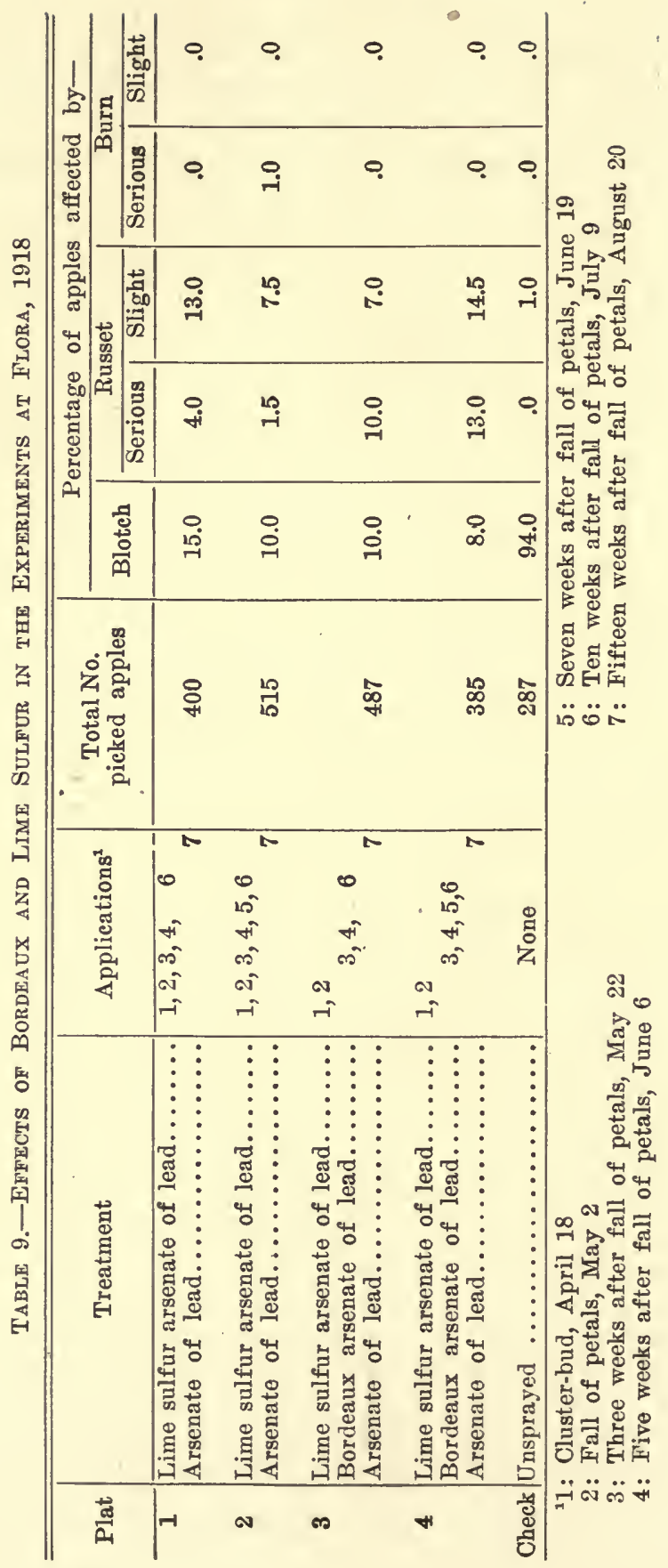


Plat 2 showed 1 percent of burn, which resulted from lime sulfur arsenate of lead applied ten weeks after the fall of the petals during very warm, dry weather.

\section{Value of Different Applications of Bordeaux and Lime Sulfur}

Experiments were continued to obtain further information with reference to the value of different applications of Bordeaux and lime sulfur in the control of blotch. The results are shown in Table 10.

Reference to the results for Plats 5 and 9 will show that lime sulfur or Bordeaux applied three weeks after the fall of the petals gave the most effective control over blotch. Applications of these materials five weeks after the fall of the petals were next in effectiveness, while sprays applied seven and ten weeks after the fall of the petals were of less value.

The amounts of russet on the different plats is rather inconsistent in variation, but there is no doubt in the writer's mind that both lime sulfur and Bordeaux caused some russeting of the fruit.

No burn was recorded.

\section{SUMmaRY OF RESULTS FOR 1918}

1. Bordeaux and lime sulfur were practically equal in the control of apple blotch.

2. The most important application of lime sulfur or Bordeaux was three weeks after the fall of the petals; and the second in im. portance, five weeks after the fall of the petals. Later applications were of little value in reducing blotch infection.

\section{INCIDENTAL OBSERVATIONS}

1. The importance of thoroness and timeliness of application in spraying for blotch was further emphasized in the work at Flora in 1918.

2. Friend and Ward spray guns were both used. It was found that the latter type gave the finer mist, but neither makes developed as fine a mist as that produced by ordinary disc nozzles.

3. Spray guns proved wasteful, applying an excess of material. More lime-sulfur injury developed on the foliage of trees sprayed with the gun than on those sprayed with disc nozzles.

4. The trees could not be sprayed properly by using one spray gun operated from the top of the tank. They were more advantageously sprayed by using a rod and dise nozzle in the tower and a rod and two disc nozzles on a $Y$, for ground spraying, than by using a rod and disc nozzle in the tower and a spray gun for ground spraying. 


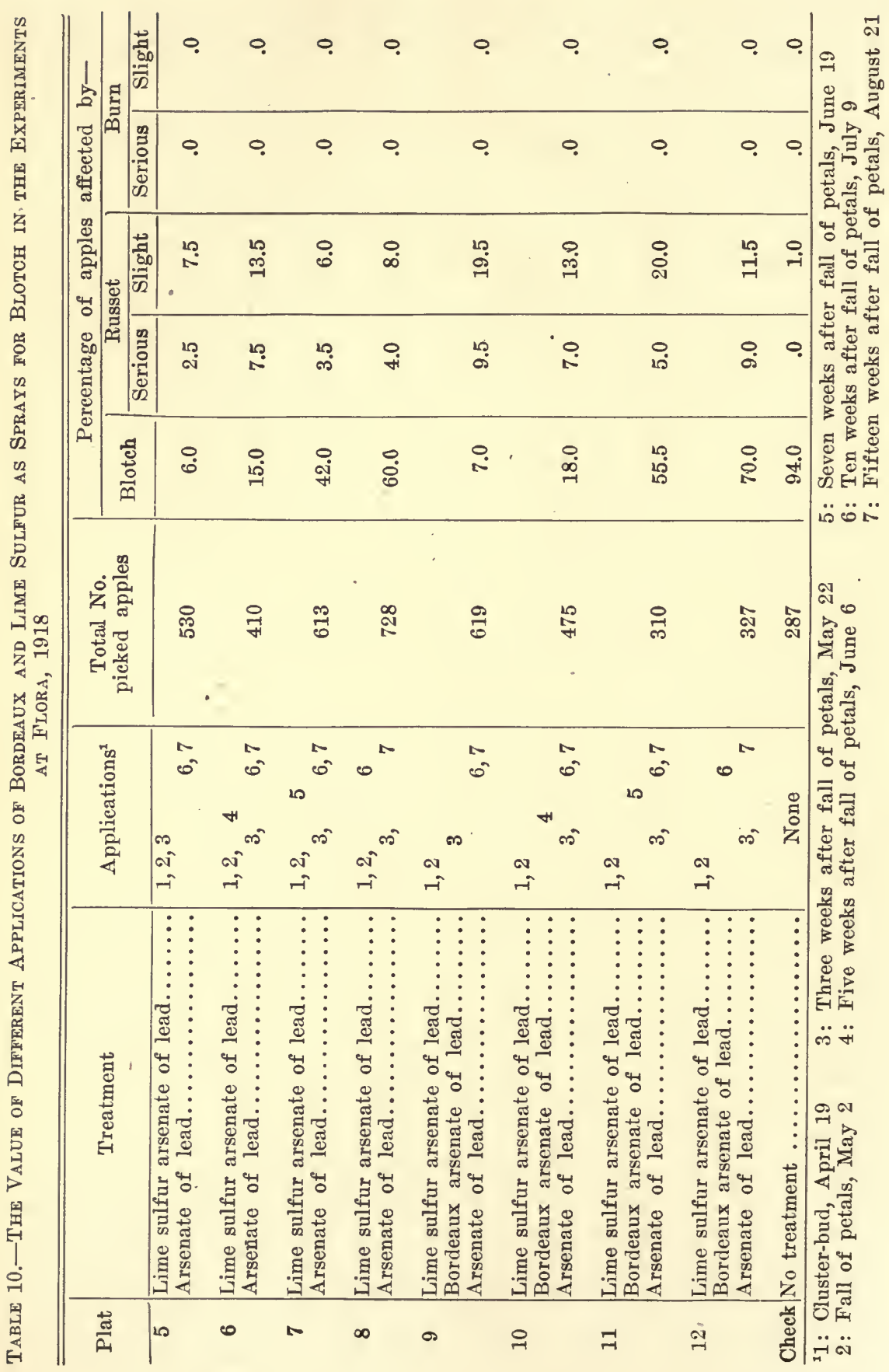


5. Apple blotch was first observed on the unsprayed fruit on June 19, seven weeks after the fall of the petals.

6. Unhealthy apple trees suffered more serious spray injury to foliage than vigorous trees.

\section{RECOMMENDATIONS FOR THE CONTROL OF APPLE BLOTCH}

The first step to take in the control of apple blotch is to remove water sprouts as they are very susceptible to blotch infection. Following this the tops of the trees should be well pruned so as to permit thoro spraying.

High pressures, from 225 to 250 pounds, should be used, driving the spray thru dise nozzles with small openings. Dises should be replaced whenever the openings wear too large to give the finest mist spray.

Trees should be sprayed thoroly but not drenched and care should be taken to apply the spray to the new wood as well as to the fruit. The interior and under parts of the trees should be well sprayed.

Sprays should be applied on time, not on certain dates, but with reference to the time of the fall of the petals.

The following schedule is recommended for blotch-infected orchards :

First Application.-The first and most important spray for apple blotch is that applied as near to three weeks after the fall of the petals as possible. Lime sulfur arsenate of lead should be used at the rate of $2 \frac{1}{2}$ gallons of lime sulfur and 2 pounds of powdered or 4 pounds of paste arsenate of lead in 100 gallons of water.

Second Application.-A second and important application of lime sulfur arsenate of lead should be applied two weeks later, or five weeks after the fall of the petals.

If apple blotch is to be controlled by spraying, the fruit must be protected during the period from four to six weeks after the fall of the petals, because this is the time of greatest infection. Applications made three and five weeks after the fall of the petals will accomplish this protection, provided heavy rains do not oecur. In the event of heavy rains following such applications, it will be necessary to apply extra sprays of lime sulfur. Bordeaux is more adhesive than lime sulfur but the danger from russet on Ben Davis at these periods, especially during wet weather, makes the use of lime sulfur more desirable. 






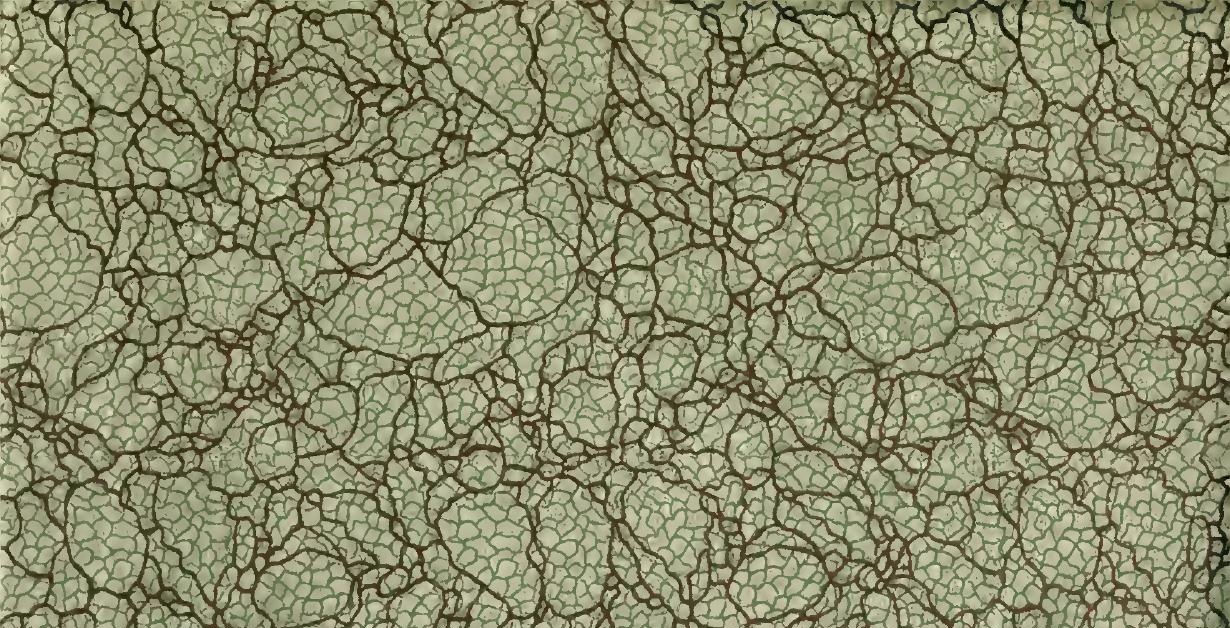


UNIVERSITY OF ILLINOIS-URBANA

Q.630.71L6B

BULLETIN. URBANA

$\mathrm{COO2}$

208-223 1918-18

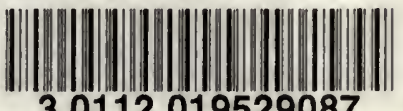

30112019529087 